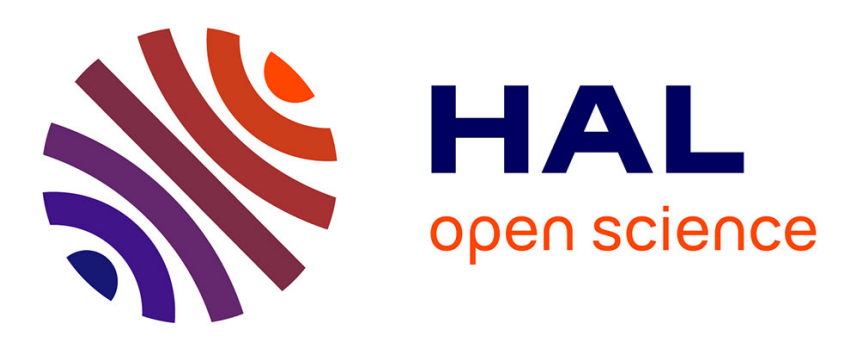

\title{
Is the private forest sector adapting to climate change? A study of forest managers in north Wales
}

\author{
Anna Lawrence, Mariella Marzano
}

\section{To cite this version:}

Anna Lawrence, Mariella Marzano. Is the private forest sector adapting to climate change? A study of forest managers in north Wales. Annals of Forest Science, 2014, 71 (2), pp.291-300. 10.1007/s13595013-0326-4 . hal-01098416

\section{HAL Id: hal-01098416 https://hal.science/hal-01098416}

Submitted on 24 Dec 2014

HAL is a multi-disciplinary open access archive for the deposit and dissemination of scientific research documents, whether they are published or not. The documents may come from teaching and research institutions in France or abroad, or from public or private research centers.
L'archive ouverte pluridisciplinaire HAL, est destinée au dépôt et à la diffusion de documents scientifiques de niveau recherche, publiés ou non, émanant des établissements d'enseignement et de recherche français ou étrangers, des laboratoires publics ou privés. 


\title{
Is the private forest sector adapting to climate change? A study of forest managers in north Wales
}

\author{
Anna Lawrence • Mariella Marzano
}

Received: 20 December 2012 / Accepted: 19 August 2013 / Published online: 18 September 2013

(C) Her Majesty the Queen in Right of United Kingdom 2013

\begin{abstract}
- Context Two-thirds of Britain's forest area is privately owned. Thus, understanding private forest owners and managers, and their attitudes to uncertainty and change, is essential for the success of climate change adaptation policies.

- Aim The aims of this study are to (1) assess how beliefs in climate change in the private sector have influenced forest management practices; (2) identify constraints related to changes in species choice and silvicultural systems; (3) analyse the implications for implementing climate change policy in forestry.

- Method Semi-structured interviews with key informants who provide advice to, or manage woodlands in, the private forest sector in north Wales.

- Results Woodland managers and some advisers are not generally convinced of a need to adapt. They feel the future is uncertain, more usually in relation to tree disease than to climate change itself. Species choice is the principle focus of adaptation activities and reveals a deep divide in opinion. Commercial advisors look to new exotics but are inhibited by absence of markets, while small-scale owners rely more on native genetic diversity.

- Conclusions Findings that are likely to apply widely include: the influential role of forest agents in forest management decisions including species choice; lack of confidence in climate change predictions, and in markets; more immediate
\end{abstract}

Handling Editor: Marc Hanewinkel

Contributions of the co-authors This research was carried out by the authors. Mariella Marzano contacted respondents and arranged most of the interviews. Interviews were conducted by both authors. Anna Lawrence conducted the Nvivo analysis and wrote the discussion and conclusions. Other sections of the paper were written jointly.

A. Lawrence $(\square) \cdot$ M. Marzano

Forest Research, Roslin, Midlothian EH25 9SY, UK

e-mail: anna.lawrence@forestry.gsi.gov.uk concerns about tree pests and diseases; demand for leadership from the public sector, and for engagement amongst the private sector. Further research is needed across a wider area to test the variability in relationship between attitudes and behaviours, and local conditions including climate change predictions.

Keywords Adaptation $\cdot$ Attitudes $\cdot$ Behaviour change . Forestry extension $\cdot$ Policy tools $\cdot$ Risk $\cdot$ Uncertainty

\section{Introduction}

1.1 Private forest owners and climate change adaptation policy

Climate change is a key driver of current forest policy in the United Kingdom (UK), and requires changes in forest management practice. The majority of woods and forests in the UK are privately owned, so policy implementation depends on the perceptions and actions of private forest owners and managers. This paper analyses the current potential for change in forest management, through a case study in one part of the UK.

Forest policy in the UK is multi-layered. The UK Forestry Standard and associated guidelines provide a framework to establish standards and incentives for SFM and the newest version includes, for the first time, climate change guidelines (Forestry Commission 2011, Buizer and Lawrence 2013). Each constituent country of the UK (England, Scotland, Wales and Northern Ireland) has its own forest strategy, which includes a response to climate change. At the UK level, the focus has largely been on mitigation but country strategies include adaptation, by promoting diversification of species choice and changing silvicultural systems (Buizer and Lawrence 2013). 
Across the UK, nearly three quarters of the forest is in private ownership (Table 1) and so the response of the private sector to forest policy goals is crucial. In contrast to many other countries where forest owners are required to produce a forest management plan, woodland owners in the UK are free to set their own objectives for woodland management or to leave them unmanaged (although not to convert forests to other land uses). The main policy tools in the UK for encouraging private owners to manage their woodlands in line with public policy, therefore, rely not so much on regulation (except in the case of tree health) but rather on provision of advice and grants.

Despite the policy emphasis on influencing the decisionmaking of private forest owners, little research has been conducted into their values, attitudes and motivations in relation to climate change, in the UK. A review of 42 studies of landowners in the UK shows that woodland owners are often described as largely uninterested in woodland management, and can be reluctant to take up grants to change this; however, conceptions of 'management' appear to differ greatly between owners and policy stakeholders (Lawrence and Dandy 2013). A quantitative survey in Wales provides more detail about one set of landowners: farmers with woodland on their land (Wavehill Consulting 2009). It found that $92 \%$ of those surveyed were using their woodlands in some way, and $93 \%$ had undertaken some kind of work in the woodlands during the last 3 years (most commonly, wildlife habitat enhancement and provision of shelter for animals). Those receiving woodland grants were more likely to have undertaken such work. None of this UK literature examines climate change adaptation.

A further literature search through Scopus using keywords such as 'adaptation', 'forests', 'owners' and 'climate change' produces papers that largely focus on modelling and longterm experiments (D'Amato et al. 2011; Duncker et al. 2012; Fürstenau et al. 2007; Ge et al. 2013; Mason et al. 2012; Seidl et al. 2011; Yousefpour et al. 2010). It also illustrates recommended management changes for adaptation, including diversification of species and structure, choice of species adapted to emerging conditions (particularly drought), increased complexity and management intensity, regional multi-ownership planning, and increased monitoring (D'Amato et al. 2011; Furness and Nelson 2012; Kolström et al. 2011; Mason et al. 2012; Seidl et al. 2011; Spies et al. 2010; Temperli et al. 2012). Only very few studies focus on the attitudes and practices of

Table 1 Area and proportion of forest in public and private ownership in the United Kingdom (source: www.forestry.gsi.gov.uk/statistics)

\begin{tabular}{lrlcrr}
\hline & England & N. Ireland & Scotland & Wales & Total \\
\hline Public (000 ha) & 214 & 61 & 481 & 114 & 870 \\
Private (000 ha) & 1,083 & 27 & 909 & 190 & 2,209 \\
\% private & 84 & 31 & 65 & 63 & 72 \\
\hline
\end{tabular}

the owners towards climate change and ask to what extent is adaptation taking place. None of these studies are from the UK. A qualitative study of forest practitioners in Germany found a wide gap between claims and implementation of climate change adaptation (Milad et al. 2012). Research in Sweden shows that private individual forest owners increased their reported adaptation activities between 1999 and 2004 (Blennow 2012). Of those who have not adapted, many reported a lack of knowledge of how to adapt. A wider survey covering Germany, Sweden and Portugal shows that an individual's strength of belief in climate change will often influence their willingness and capacity to adapt (Blennow et al. 2012). In Canada, Furness and Nelson (2012) surveyed 38 member organisations of the British Columbia Community Forest Association and found that $32 \%$ were already incorporating adaptation strategies into their management while $45 \%$ were currently researching adaptation. Those who were engaged or interested in adaptation were more likely to be concerned about global climate change and had observed or expected to see impacts of climate change. Nevertheless, $63 \%$ of participants were still unsure what to do about it.

From this overview of the literature, we can conclude that there is no consistent pattern of forest management response to climate change, but that in the private sector in highly forested countries such as Sweden and Canada, there is some indication of changing practice, combined with some uncertainty about how to adapt. How do these issues compare in the UK? This paper addresses this question through a case study in Wales, which aims to: (1) assess how beliefs in climate change in the private sector have influenced forest management practices; (2) identify constraints related to changes in species choice and silvicultural systems; (3) analyse the implications for implementing climate change policy in forestry.

\subsection{Case study site}

North Wales was selected for this study, because it provides a range of private ownership scenarios typical of those across the UK; and because existing on-going research there provided good contacts with key informants. Woodland cover in Wales has increased over recent decades, to around $14 \%$, although it is still one of the least wooded areas of Europe (Forestry Commission 2012a). Of this, about 84,000 ha (or more than $70 \%$ ) consists of Sitka spruce (Picea sitchensis) largely managed under patch clearfelling systems on 3550 year rotations (Mason and Perks 2011). Projected impacts of climate change are variable even within the study area; overall productivity is expected to increase but there is increased risk of summer drought, winter flooding and extreme wind events, as well as pest and disease outbreaks (Ray 2008a). Responding to climate change is a strategic theme of the Welsh forest strategy 'Woodland for Wales' (WfW) with a focus on resilience through woodland creation, increasing 
species diversity and sustainable management (Welsh Assembly Government 2009). Consequently, there is a policy shift away from the non-native monoculture plantations favoured in the twentieth century towards greater diversity of species, provenance, age, and structure within woodlands.

At the time of research (2011-12), the grants system in Wales was changing from the Better Woodlands for Wales (BWW) grants scheme (2006-2010), to the Glastir Woodland Creation Grant scheme (2010-11) and the Glastir Woodland Management scheme (2012-13). The BWW offered grants to land managers to encourage woodland creation and facilitate management of existing woodlands, and was linked to the WfW objectives on climate change. Glastir is a new Welsh Government agri-environment scheme which aims to increase environmental benefits on Welsh farms; non-farming landowners and community groups are also eligible for grants. At the time, Forestry Commission Wales was the government body responsible for implementation of policy. It had published guidance for the private sector, on increasing tree species diversity, and on diversifying silvicultural systems (Forestry Commission Wales 2010, 2012). It had invested in seminars to promote these, particularly the guide for increasing tree species diversity in Wales.

\section{Material and methods}

Studies in countries such Sweden and the USA benefit from access to a complete database of forest owners; this is lacking in the UK. Given the absence of prior research, the welldocumented challenges in accessing owners, and the fact that forest management decisions are often made by agents (Lawrence and Dandy 2013), we take a different approach. Following established social research practice (Bryman 2001), and a number of precedents in the forestry sector (Hokajärvi et al. 2009; Milad et al. 2012), meaningful data can be collected from qualitative in-depth interviews with small samples of 'key informants' who hold key positions of expertise or experience, and who collectively cover the stakeholder perspectives on an issue. 'Key informants' are individuals who have specialist knowledge about an issue, are often able to give an overview of different perspectives, and are able to provide high quality, information rich data in a relatively short period of time (Marshall 1996; Gilchrist and Williams 1999). We focused our research on stakeholders who have knowledge of the attitudes and actions of a wide range of landowners in north Wales. These stakeholders include community woodland group leaders, local authorities, large landowning NGOs, estate managers, a timber industry membership organisation and forestry agents. Forestry agents are consultants (ranging from the self-employed to large international forest management companies) who provide advice and services to private owners on all aspects of sustainable forest management (e.g. grant applications, forest design plans, certification, timber harvesting and marketing).

Selection of key informants was purposive and based on recommendations from Forestry Commission staff and a published register of land agents in the area. A 'snowballing' approach was used (Bryman 2001) to identify and select representatives with experience of forest management and adaptation to climate change, and who were also professionally knowledgeable about other owners and managers in their communities. In total, 24 people were contacted by email, of whom 18 replied and 12 were selected based on their interest in the topic and availability for interview. Eight interviews with key informants were conducted face-to-face either in the forest or in an office setting. Four interviews were conducted by telephone.

We conducted in-depth qualitative semi-structured interviews lasting up to $1 \mathrm{~h}$, based on guide questions developed from the findings of a literature review (Lawrence and Gillett 2011). Following an introduction to the study, the interview guide focused on: (1) issues around current forest management practices and factors that may influence decision-making, (2) perceptions of climate change and of the need to adapt forest management, (3) any observed experimentation and innovation in the forest, (4) levels of advice and support needed to adapt to climate change and (5) information sources used.

All interviews were recorded, transcribed and coded using Nvivo 8 (www.qsrinternational.com). Open coding starts with broad coding categories based on the interview guide (Bryman 2001). These are then refined and arranged into key themes, to provide the structure of the results section which therefore reflects the importance attached to particular themes by respondents, rather than the structure of the interviews. The data consists of quotations selected to represent particular viewpoints and to illustrate respondents' mode of expression, which ranged from hesitant to confident.

\section{Results}

\subsection{Owner types and motivations}

We asked respondents to describe the different types of woodland owners, in terms that were useful for management. These are summarised in Table 2, and indicate a mixture of economic and other motivations. This mixture of management objectives was described as widespread, but hampered by poor markets for hardwoods, so that commercial objectives are associated largely with the planted exotic conifer forests.

\subsection{Climate change and adaptation}

There was a consensus that neither woodland owners nor forest managers are very worried about climate change. Ten 
Table 2 Categories of woodland owners identified by respondents

\begin{tabular}{|c|c|c|}
\hline $\begin{array}{l}\text { Type of owner (identified } \\
\text { by respondents) }\end{array}$ & Comments about motivations (made by respondents) & $\begin{array}{l}\text { Comments about woodland resource } \\
\text { (made by respondents) }\end{array}$ \\
\hline Individual investors & $\begin{array}{l}\text { Motivated by profit. Seen as a 'new' category of owner, } \\
\text { difficult to generalise about objectives, but drawn by } \\
\text { tax incentives (woodland ownership and income is } \\
\text { free of inheritance and income tax) }\end{array}$ & $\begin{array}{l}\text { Where income is the motive, mostly conifer } \\
\text { plantations. Others more concerned with capital } \\
\text { growth, more open to broadleaf or mixed woodlands }\end{array}$ \\
\hline Individual 'weekend woodlanders' & $\begin{array}{l}\text { A place to enjoy with the family. Usually little forestry } \\
\text { experience and not much active management but } \\
\text { they do have an interest in their woodlands }\end{array}$ & Mixed or broadleaves \\
\hline Farmers & $\begin{array}{l}\text { Not that interested in forestry. Woodlands mainly in } \\
\text { areas on the farm that cannot be used for agriculture }\end{array}$ & \\
\hline Forest management companies & Motivated by profit & Almost entirely conifers — largely Sitka spruce \\
\hline Private traditional estates & $\begin{array}{l}\text { Owners considered to be older and, in some cases, } \\
\text { more sceptical of climate change. The younger } \\
\text { generation are more likely to hire management } \\
\text { companies. Forestry is often secondary to hunting } \\
\text { (pheasant) although the firewood market and } \\
\text { growing high quality timber are also options. Some } \\
\text { of the large estates rely on their woodlands for } \\
\text { heating, as biomass boilers become more common }\end{array}$ & $\begin{array}{l}\text { Largely consists of a mixture of broadleaves, a fairly } \\
\text { lowland setting up to the more commercial blocks } \\
\text { which are mainly spruce and up in the uplands }\end{array}$ \\
\hline $\begin{array}{l}\text { Community groups-from } \\
\text { cooperatives with four members, } \\
\text { up to groups of } 300 \text {; a growing } \\
\text { category }\end{array}$ & $\begin{array}{l}\text { Focus on local wellbeing as well as local energy } \\
\text { security }\end{array}$ & $\begin{array}{l}\text { A wide variety: can include commercial conifer } \\
\text { plantations, often with longer term aspirations to } \\
\text { convert to deciduous native woodlands and to } \\
\text { combine production with other objectives }\end{array}$ \\
\hline
\end{tabular}

of the 12 respondents indicated low levels of concern amongst clients and colleagues. For example:

I think there's probably an awareness of climate change but I don't know, I'm not sure that the connection's been made between climate change and growing the trees. [Commercial agent]

Some felt that climate change was mentioned only because it was one of the criteria for grant applications:

Some of the species they say they're choosing because of climate change, but I'm not massively convinced, I think [instead their aim is] replanting the native woodland and "I like these trees". [Government grants advisor]

According to the commercial agents, foresters are not convinced of the importance of climate change either:

Climate change is all very difficult isn't it? You won't be here to harvest those trees you've just planted and climate change is even more kind of abstract in a way isn't it? [Industrial sector representative]

We don't strongly take climate change into consideration really ... I mean it's really sort of just emerging isn't it in forestry? [Commercial agent]

In contrast, the two respondents from the conservation sector expressed a lot of concern about climate change. The two respondents from community groups both noted that while people may be concerned about climate change, they connect this to a need to save energy rather than to plant or manage trees.

Instead of species choice or structural diversification, respondents focused largely on tree health when asked about the effects of climate change. Half of the respondents mentioned Phytophthora ramorum, which is having a major impact on forestry in Wales (Forestry Commission 2012b).

I don't think it's the end of forestry but when you see Phytophthora coming in, you get red band needle blight having an effect, goodness knows what else is round the corner ... you can't help but think, is this all part of climate change as well? [Commercial agent]

Not everyone agreed there was a need for behaviour change:

The impact upon an existing woodland with climate change I think is not going to be that great for 20 years or so, probably even 50 years, because there's so much variation within the native species. [Local government advisor]

All of this adds up to very little perceived behaviour change:

People are resistant to change and forestry happens on such a slow kind of speed of change. [Industrial sector representative]

I think climate change is just something that's there and I think the majority probably aren't really considering it. [Government grants adviser] 


\subsection{Species choice}

Species choice is where we see the deepest divide in responses. There are three main views: rely on native diversity; stick with the tried-and-tested Sitka spruce; or plant a wide range of new species. The following three quotations illustrate each of these views:

I always try to push people towards the more native side, because I think there's so much variation within those species that you hopefully are turning woodlands into something that's more adapted to climate change. [Local government advisor]

So then they read ... all the stuff that comes out of the Forestry Commission and they conclude that actually we've got at least another rotation of Sitka Spruce, we're in enhanced Sitka Spruce growing conditions, therefore we don't need to do anything about it. [Industrial sector representative]

[There are those who] have this really weird view of what's native and what isn't. And they want birch, sessile oak, alder, willow, holly, maybe a little bit of hazel. And to them Scots pine isn't even native. Whereas I'm arguing Pinus pinaster, I'm talking about using walnut, sweet chestnut and that's heresy to them. [Independent consultant]

A few talked about provenance as well as species, but with less confidence:

Maybe we have to start thinking about, well let's start planting trees from southern provenances but how difficult they would be to establish up this far north I don't know. [Commercial agent]

In addition to climate and disease, a third uncertainty about the value of planting different species, is markets:

What I have been proposing in some of these woodlands is to start to underplant [with] Silver Fir and the reaction I get back, "oh there's no market for Silver Fir in this country" [Commercial agent]

If we moved on to Japanese Red Cedar ... it does grow quite well, selling it is a nightmare. [Commercial agent]

Many do however see a need for change towards more attention to matching species with site conditions:

Far too much in the past we've tried to force species to grow on sites that are completely unsuitable, I think we've got to go completely away from that and plant trees that will grow where they want to grow rather than saturating it with fertilisers [Estate manager and consultant]

When we're looking at woodlands that are products of non natives then I do start to wonder and I think some of the practices that we've got at the moment... we're not going to be able to carry on. [Local government advisor]

\subsection{Adaptive management}

None of the respondents were doing adaptive management for climate change. Adaptiveness requires experimentation but when asked directly, every commercial respondent said they were not experimenting. Two felt that the Forestry Commission actively discourages divergence from planned management, in both the public forests and private sector (where it influences behaviour through grants).

Probably what I didn't like in my time working with the Forestry Commission is that you used to get told off at the end of the day for using your initiative whereas in the private sector you're expected to use your initiative. So as long as you can justify your actions you can go ahead. [Commercial agent]

There is demand for more opportunities to learn from research demonstration sites, and a two-way approach to knowledge exchange (rather than knowledge transfer). In contrast, both respondents who work with community woodlands described a range of experiments based on close observation of the site. Again they described this as being discouraged or even disqualified by the Forestry Commission (who own the land and with whom the community group have a management agreement).

Several foresters (agents and government advisors) saw their most innovative work in the development of continuous cover forestry, which can be seen as a form of adaptive management because of the high levels of monitoring required (Lawrence and Gillett 2011). There is some grant support for continuous cover forestry (CCF), and in this context, the Welsh Government does encourage change:

The current grant scheme is great because ... there's a focus to go to CCF but it's been at that low key of let's just start encouraging people. [Government grants advisor]

\subsection{Risk and uncertainty}

Beyond the specific questions of species choice or silvicultural system, the interviews focused on the more abstract concepts of risk and uncertainty. Several respondents described investment forestry as essentially risk averse:

Everybody [in the commercial forestry sector] works on a discounted revenue flow and ... it gets very risk averse ... they're looking for something that can give them 
income generation at a certain level of $3 \%$ to $5 \%$ rate of return on capital investment [Commercial agent]

Such is the level of perceived risk aversion in forestry generally that some advisors are sceptical when a grant applicant wants to take high risks, for example with heavy thinning to convert to continuous cover forestry.

When comparing private and public forestry, some felt the private sector had more freedom to try out new approaches.

Done correctly the private sector possibly does have a better chance of implementing [adaptation] because [...] as long as our clients are happy for us to go ahead with that and it's on a good basis that we're taking that sort of line in the management of the woods. [Commercial agent]

Others felt the public sector had more ability to take on risk, and should lead the way by experimenting and demonstrating adaptation.

Respondents talked more comfortably about uncertainty than about risk. Uncertainty was a primary reason given for not changing. The following quotation illustrates the hesitancy often expressed:

I don't know, I'm still not $100 \%$ certain ...I just think we don't know, it's certainly unknown...even with good advice [from] people [who] have thought about these things, the unknowns like diseases and other things happen that mean that perhaps that advice is very quickly discarded. [NGO woodland advisor]

In particular, respondents expressed uncertainty about choosing suitable species, for example:

I think we're probably thinking that we might want to have a change of species. But quite what that change of species is we don't know because pine isn't really going to be an option for us, larch isn't an option. [We have] problems rather than the solutions. We moved against total Sitka because we feel that narrowing the genetic pool to that extent is probably too much ... [or] do we move back to using Washington or Oregon Sitka rather than using improved Sitka? [Commercial agent]

Several people had examples of advice they had previously given which had later proven unsuitable - with hindsight they regretted recommending pine (subsequently attacked by Dothistroma), horse chestnut (subsequently attacked by bleeding canker) and others. In the case of smaller woodlands focusing on broadleaves, other constraints were emphasised:

There are big grant incentives now to plant native broadleaves but one of your key native broadleaves throughout the country is an oak tree isn't it? And it's just not going to happen, it's not only north Wales, it is a national problem with grey squirrels. [Industrial sector representative]

The mix of risk and uncertainty is highlighted by one plan, where the respondent describes the expected benefits of the woodlands becoming more ash-dominated:

...because ash comes in very naturally when we fell trees. And that may well be a sensible approach for climate change ... and those are going to have some genetic variation and some may hopefully be more adaptable or capable of living with drier summers and wetter winters and disease resistance and others. [NGO woodland advisor]

Since this interview, the arrival and spread of ash dieback disease Chalara fraxinior has made ash an unlikely species on which to rest one's hopes for climate change adaptation (Pautasso 2013).

\subsection{Policy and grants}

Respondents recognised that forest policy in Wales is connected with climate change, but were sceptical about its effectiveness:

I think the policy in Wales ... using the mixtures ... is probably slightly premature and... that thinking needs to be better explained to the private sector. ...I think we want to see evidence before we throw money at it, you know? [Commercial agent]

The worry you have with all these things is that sudden changes of policy and things tend to go in and out of fashion very quickly because that's how politicians work - and climate change is long term, of course it's long term and we need to have long term plans. [Commercial agent]

Policy is delivered through a mixture of grants and information services. Several pointed out that where owners apply for grants they do not necessarily see the connection with climate change and policy drivers:

Even people who are looking to create woodlands under the Glastir Woodland Creation Scheme, which is supposedly a carbon reduction scheme, very few people seem to understand what the Welsh government are trying to achieve through that. [Local government advisor]

Doubts were expressed about the ability of grants to influence all owners:

Landowners [are] on a sort of continuum. Some of them are very pro Forestry Commission. Other ones ... won’t 
take any grants. They'll plant trees but they'll do it without the grants. [Independent adviser]

One respondent was optimistic that more owners were becoming engaged through grants:

One sees a lot of good incentives now, the new Glastir schemes and things like that, farmers are incentivised to put something back into the woodlands really, historically they were just neglected areas. [Commercial agent]

\subsection{Information sources}

It is difficult to distinguish between the effects of grants, and of advice, because the two are usually supplied together. Advisory services fall into three main patterns: the commercial investment forests, and estates, which employ a manager or consultant; small woodlands in receipt of grants, which have access to the advisory services provided by FCW, local authorities, etc.; and those who either have no access, or are unaware or uninterested in access advice. Agents described how they would not necessarily be responsible for long-term management but they are often called in to advise on specific issues, such as harvesting, or dealing with a new disease.

Owners from all sectors are seen as heavily reliant on external advice.

People who end up as the key players within [community woodland] groups very often can't tell one tree from another. [Community woodland organiser]

I have people phoning me up with very varying degrees of woodland management knowledge ... A lot of the time you go there and look at the woodland and they say, well what do we do with it? [Estate manager and commercial consultant]

In a lot of situations our clients rely on us to be giving them the right advice for managing their woodlands. [Commercial agent]

Some felt that the advice options for owners outside the commercial/estate sector, were disconnected and confusing particularly in relation to species choice:

The Forestry Commission has come out with things saying, plant species from southern France. So I get people coming up to me, I've got a native oak woodland and they're saying plant species from southern France, what am I supposed to do? I say, ignore it just carry on with what you're doing [Community woodland organiser]

So, a key question is where those agents get their information from, and how they understand and prioritise climate change. The main information sources described by respondents are FCW (particularly seminars to disseminate the Read
Report (Read et al. 2009), and to promote new species guidance); the website of the foresters' professional association, the Institute of Chartered Foresters (ICF); and Forest Research (through particular events, and individuals who are seen as key in interpreting it). There was no single dominant source of information; some regularly tried to update themselves from the FR website, others (but not all agents) were members of ICF.

Realistically we don't get a lot of time to indulge ourselves in [knowledge transfer] but just over a year ago, a year past in the summer, Forest Research in Wales held a climate change and species choice seminar and that was very useful and that was where I saw the projected models of best scenario and worst scenario. [Commercial agent]

One respondent who had worked in both public and private forestry felt that he was more cut off from new research and information in the private sector. Others lamented poor flow of information and experience sharing amongst private owners, particularly between estates and commercial plantations. At the same time, many respondents felt saturated with information:

I don't want any more emails! ... we work in the commercial world where things seem to get speedier and speedier in terms of client demand but there's less time to spend doing the important bit. [Commercial agent]

Overwhelmed, overwhelmed with information. Too much! [NGO forest manager]

The agents reported that seminars are more valuable than study tours. At the time of our interviews, FCW had recently held a series of seminars to promote their new species guidance, and all our respondents from the commercial sector had attended and found them valuable. Speaking more generally about seminars, some respondents described how they filter information through personal experience:

Very specific technical/scientific seminars are probably the most useful. But ... you can quiz how the result's derived and being a practitioner why they make good practical sense or not $[\ldots]$, that's where you either [decide] it's a load of old nonsense [or] "oh I could try that because I think this'll happen" and usually when foresters are thinking like that it will happen, it does. [Commercial agent]

I don't quite believe the seed mapping zones that the Forestry Commission produce but that's what there is to go on. [Local government adviser]

Some expressed frustration that colleagues in forest management companies were not thinking collectively about 
climate change and adaption, and that this was placing them in a risky position:

There's real inertia to actually having a full discussion and then develop the thinking pattern on it ... All we need is a few bad winters or high storms or something and then climate change will be mentioned and clients are going to be asking for information. [Commercial agent]

\section{Discussion}

This study aimed to assess how beliefs in climate change in the private sector have influenced forest management practices, identify constraints related to changes in species choice and silvicultural systems, and analyse the implications for implementing climate change policy in forestry. In focusing on a set of key informant interviews in a defined area, the study identifies the issues that are perceived to influence behaviour; it does not provide a description of actual behaviours. We argue that this is more useful currently, for three reasons: (1) the level of climate change adaptation is very low and difficult to measure; (2) where some apparently adaptive actions have been taken they are not usually the result of climate change concerns and so 'belief' cannot be inferred from action; and, (3) in order to engage more effectively with land owners and managers, there is a need to understand perceptions and motivations if policy is to be more effectively implemented.

In an area of mixed landownership, we would expect a range of views. Against this expectation, it was notable that there is a very consistent and widespread reported lack of engagement with climate change. All except two respondents, all with wide knowledge of landowner behaviour in the area, described this trait; only the conservation organisations described immediate concern and action. This finding is more extreme than any of the studies highlighted in the introduction. In Sweden, between $14 \%$ (in the north) and $23 \%$ (in the south) of forest owners reported that climate change had affected their forest management in 2004 (an increase since 1999) (Blennow 2012). In British Columbia, researchers were surprised by the level of adaptation amongst community forest organisations, where about a third of organisations interviewed had already taken action (Furness and Nelson 2012). These studies used different methods but to date are the only ones available for comparison. With time, further evidence from a wider geographical range will enable researchers to explore these differences and to make links between context, and response to climate change.

One factor that may be influencing the low level of engagement with climate change is that in north Wales, climate change predictions are neither certain nor particularly adverse
(Ray 2008a). Forest managers are in effect being asked to respond to policy and to their own convictions and values, rather than to on-the-ground evidence of changing conditions. This contrasts with conditions described elsewhere, for example in Canada where drought, fire, insect outbreaks and tree disease are cited as climate change impacts (Daniels et al. 2011; Parkins and MacKendrick 2007) and attributed as causes of community forest action (Furness and Nelson 2012).

On the other hand, tree health is a driver for concern if not yet action; despite the heavy reliance on Sitka spruce in north Wales, many respondents were aware (and reported awareness amongst clients and colleagues) of the outbreak of Phytophthera ramorum and its very serious impacts on forest management in south Wales where larch is more widely planted. All landowners with infected trees have been issued with notices under Plant Health (Forestry) regulations, to fell the infected areas. In total, across the UK, about 3,000 ha of larch trees are being felled (Forestry Commission 2012b). Despite a complex of causal factors (Pautasso 2013), for forest owners in Wales this is the tangible effect of climate change.

Looking more closely at the differences between stakeholders, almost all respondents saw species choice as an essential part of future forestry, but there were two quite distinct views on what shape this should take. On both sides, views were held with conviction. Roughly, the distinction is between commercial advisors who look to new exotics (such as Silver Fir) for the potentially adapted trees of the future, while smaller scale owners, giving lower priority to commercial objectives, rely more on native genetic diversity. Our purpose here is not to suggest a fundamental split between types of stakeholders, but rather to conclude that there are two very different approaches, and most respondents adhered strongly to one viewpoint or the other (natives, or exotics). In contrast there was little evidence of significant shifts in thinking about silvicultural systems, or adaptive forest management, except where connected with efforts to introduce new species. There is enthusiastic support for continuous cover forestry amongst a small group of aficionados, with associated research (e.g. Pommerening 2006; Pommerening and Murphy 2004) but at the level of general practice discussed in this study, adoption is not very evident.

The findings provide some entry points for more effective policy implementation. Climate change policy in Welsh forestry is at an early stage, and the evidence here suggests that owners and managers are motivated less by conviction and concern about climate change, and more by the principle values they hold towards woodland management, and hence for example attitudes towards species choice. This study shows that grants often steer behaviour towards particular species without making any connection to climate change agendas. For those who are interested in grants, changing the grant conditions (e.g. to require a wider range of species) would be an effective incentive. However, grants do not 
influence all woodland owners (Lawrence and Dandy 2013; Wavehill Consulting 2009) and other options are also necessary. Seminars, where forestry agents are able to discuss and question such messages, are seen as a welcome and useful approach. Framing messages about adaptation in terms of tree health concerns as well as climate change could increase effectiveness.

The evidence from this study is that there are two other areas in which change could be stimulated. The first simply responds to the most frequently mentioned constraint to species diversification: the need to increase market confidence in less familiar species. The other is less direct, but implied by the frequency with which respondents highlighted the issue of engagement between the public and private sectors. Despite the existence of several forums where professionals from both sectors meet, and despite the fact that many have been employed in both sectors, our study highlights a perceived failure to take advantage of the strengths of each. Some see a role for the public forest to lead on risk taking and demonstration, being large enough to absorb risks by trying out alternative species or silvicultural systems. Others highlighted the freedom from constraints of bureaucracy and public opinion in private forests, and advocated greater use of its flexibility and freedom to experiment. Both sets of views saw the public forest sector as risk averse, and inclined to discourage innovation; nevertheless it is from here that research is emerging on potential new forestry species and providing some cautious advice (e.g. Willoughby et al. 2007).

\section{Conclusions}

To what extent can we generalise from this first study of climate change attitudes and responses amongst forest managers? North Wales is representative of some widespread conditions in the UK, and in other ways less typical.

Some aspects of our findings are likely to apply widely across the UK: the influential role of forest agents in forest management decisions including species choice; the lack of confidence in climate change predictions, and in markets; the more immediate concern about tree pests and diseases; the demand for leadership from the public sector, and for engagement amongst the private sector.

Less easy to generalise are the links between these findings and specific conditions of predicted climate change. Uncertain though they are, there are clear distinctions in expected direction of change across different parts of the UK affecting the anticipated influence of drought, flooding and wind (Ray 2008a, b; Ray et al. 2010). The ways in which government might want forest managers to adapt are related to these differences, as are the incentives and programmes on offer to encourage landowners to change their practices.
Nevertheless, climate change predictions may not affect overall attitudes, for two reasons. First, place-specific predictions of change were not reported as a factor in this study. No respondent related the beliefs and actions of his or her clients and colleagues to specific local predictions of change. Instead, they framed them in terms of more general beliefs about climate change, and focused on constraints of information and markets. Second, many forest management agents are working across a wide area, with clients experiencing a range of climate and environmental conditions.

Experience and anecdote give us grounds to expect that the attitude of forest managers and agents to the general need for adaptation, and their awareness and attitude to the incentives and options available, may be similar across the country, and that our findings may therefore be widely applicable. Testing this is the next challenge for research. Quantitative studies to pick up on fine grained differences of attitude and behaviour, and qualitative studies across a wider area to identify stakeholders' explanations for such attitudes and behaviours, will develop the conclusions of this study and provide robust evidence to support more effective adaptation in the private and public forest sectors across the UK.

Acknowledgments We would like to thank all the respondents who participated in this study and two anonymous reviewers for their comments on the manuscript.

Funding This research was funded through the 7th Framework Programme (FP7) of the European Union (Project MOTIVE, ENV-CT-2009226544); further time for analysis and writing was funded by the Forestry Commission.

\section{References}

Blennow K (2012) Adaptation of forest management to climate change among private individual forest owners in Sweden. For Pol Econ 24: $41-47$

Blennow K, Persson J, Tomé M, Hanewinkel M (2012) Climate change: believing and seeing implies adapting. PLoS ONE 7

Bryman A (2001) Social research methods. Oxford University Press Centre, Exeter, $608 \mathrm{pp}$

Buizer M, Lawrence A (2013) The politics of numbers in forest and climate change policies in Australia and the UK. Env Sc Pol

D'Amato AW, Bradford JB, Fraver S, Palik BJ (2011) Forest management for mitigation and adaptation to climate change: insights from long-term silviculture experiments. For Ecol Man 262:803-816

Daniels LD, Maertens TB, Stan AB, McCloskey SPJ, Cochrane JD, Gray RW (2011) Direct and indirect impacts of climate change on forests: three case studies from British Columbia. Can J Pl Path 33:108-116

Duncker PS, Raulund-Rasmussen K, Gundersen P, Katzensteiner K, De Jong J, Ravn HP, Smith M, Eckmüllner O, Spiecker H (2012) How forest management affects ecosystem services, including timber production and economic return: synergies and trade-offs. Ecol \& Soc 17:17

Forestry Commission Wales (2010) A guide for increasing tree species diversity in Wales. Grants and regulations. Forestry Commission Wales. $41 \mathrm{pp}$ 
Forestry Commission (2011) The UK Forestry Standard. Forestry Commission, Edinburgh, $108 \mathrm{pp}$

Forestry Commission Wales (2012) Guidance for the use of silvicultural systems to increase woodland diversity. Forestry Commission Wales. 23 pp.

Forestry Commission (2012a) Forestry Statistics 2012 - Woodland Areas and Planting

Forestry Commission (2012b) Phytophthora ramorum in larch treesUpdate. Forestry Commission. Accessed 18 August 2013 http:// www.forestry.gov.uk/forestry/INFD-8EJKP4

Furness R, Nelson H (2012) Community forest organizations and adaptation to climate change in British Columbia. For Chron 88:519-524

Fürstenau C, Badeck FW, Lasch P, Lexer MJ, Lindner M, Mohr P, Suckow F (2007) Multiple-use forest management in consideration of climate change and the interests of stakeholder groups. Eur J For Res 126:225-239

Ge ZM, Kellomäki S, Peltola H, Zhou X, Väisänen H (2013) Adaptive management to climate change for Norway spruce forests along a regional gradient in Finland. Clim Change 118:275-289

Gilchrist VJ, Williams RL (1999) Key informant interviews. In: Crabtree BF, Miller WL (eds) Doing qualitative research, 2nd edn. Sage, London, pp 73-88

Hokajärvi R, Hujala T, Leskinen LA, Tikkanen J (2009) Effectiveness of sermon policy instruments: forest management planning practices applying the activity theory approach. Silv Fenn 43:889-906

Kolström M, Lindner M, Vilén T, Maroschek M, Seidl R, Lexer MJ, Netherer S, Kremer A, Delzon S, Barbati A, Marchetti M, Corona P (2011) Reviewing the science and implementation of climate change adaptation measures in European forestry. Forests 2:961-982

Lawrence A, Dandy N (2013) Private landowners' approaches to planting and managing forests in the UK: what's the evidence? Land Use Pol. In press

Lawrence A, Gillett S (2011) Human dimensions of adaptive forest management and climate change: a review of international experience. Forestry Commission research report. Forestry Commission, Edinburgh, $52 \mathrm{pp}$

Marshall MN (1996) The key informant technique. Family practice 13: 92-97

Mason B, Perks MP (2011) Sitka spruce (Picea sitchensis) forests in Atlantic Europe: changes in forest management and possible consequences for carbon sequestration. Sc J For Res 26:72-81

Mason WL, Petr M, Bathgate S (2012) Silvicultural strategies for adapting planted forests to climate change: from theory to practice. J For Sc 58:265-277

Milad M, Schaich H, Konold W (2012) How is adaptation to climate change reflected in current practice of forest management and conservation? A case study from Germany. Biod \& Cons 1-22
Parkins JR, MacKendrick NA (2007) Assessing community vulnerability: a study of the mountain pine beetle outbreak in British Columbia, Canada. Glob Env Ch 17:460-471

Pautasso M (2013) Phytophthora ramorum - a pathogen linking network epidemiology, landscape pathology and conservation biogeography. $\mathrm{CAB}$ reviews: Perspectives in Agriculture, Veterinary Science, $\mathrm{Nu}-$ trition and Natural Resources 8.14 pp.

Pommerening A (2006) Transformation to continuous cover forestry in a changing environment. For Ecol Man 224:227-228

Pommerening A, Murphy ST (2004) A review of the history, definitions and methods of continuous cover forestry with special attention to afforestation and restocking. For 77:27-44

Ray D (2008a) Impacts of climate change on forestry in Wales, Forestry Commission Research Note 301.8 pp.

Ray D (2008b) Impacts of climate change on forestry in Scotland - a synopsis of spatial modelling research, Forestry Commission Research Note $101.8 \mathrm{pp}$

Ray D, Morison J, Broadmeadow M (2010) Climate change: impacts and adaptation in England's woodlands, Forestry Commission Research Note $201.16 \mathrm{pp}$

Read DJ, Freer-Smith PH, Morison JIL, Hanley N, West CC, Snowdon P (2009) Combating climate change: a role for UK forests. An assessment of the potential of the UK's trees and woodlands to mitigate and adapt to climate change. The Stationary Office, Edinburgh, $242 \mathrm{pp}$

Seidl R, Rammer W, Lexer MJ (2011) Adaptation options to reduce climate change vulnerability of sustainable forest management in the Austrian Alps. Can J For Res 41:694-706

Spies TA, Giesen TW, Swanson FJ, Franklin JF, Lach D, Johnson KN (2010) Climate change adaptation strategies for federal forests of the Pacific Northwest, USA: ecological, policy, and socio-economic perspectives. Lands Ecol 25:1185-1199

Temperli C, Bugmann H, Elkin C (2012) Adaptive management for competing forest goods and services under climate change. Ecol Appl 22:2065-2077

Wavehill Consulting (2009) A survey of farmers with woodland on their land. A report for the Forestry Commission Wales. Wavehill Consulting. $62 \mathrm{pp}$

Welsh Assembly Government (2009) Woodland for Wales: the Welsh Assembly Government's strategy for woodlands and trees. Forestry Commission Wales. $49 \mathrm{pp}$

Willoughby I, Stokes V, Poole J, White JEJ, Hodge SJ (2007) The potential of 44 native and non-native tree species for woodland creation on a range of contrasting sites in lowland Britain. For 80:530-552

Yousefpour R, Hanewinkel M, Le Moguédec G (2010) Evaluating the suitability of management strategies of pure Norway spruce forests in the Black Forest area of Southwest Germany for adaptation to or mitigation of climate change. Env Man 45:387-402 